\title{
Introduction
}

Afghanistan, especially when compared with other countries in the three major regions in its area-Central Asia, the Middle East, and South Asia - is known for the variety of its physical features, climate, inhabitants, languages, religious beliefs, and modes of life. Thus, although Afghanistan constitutes a part of each of these regions, it has its own distinct characteristics.

Its habitable parts consist of both numerous long green river valleys sandwiched by lofty mountains and oases dotted in vast deserts stretching toward the fringes of the country. Being accessible almost from all sides and situated in the heart of Asia on the main ancient routes that led to these three regions, this land has been open for penetration to waves of people throughout its long history. From this fact a number of things have followed. The country has been under strong pressure from its neighbors, much as Germany has been in Europe. Its frontiers have, therefore, fluctuated over time until they were finally demarcated in the last quarter of the nineteenth century. Before the discovery of sea routes, when Afghanistan was a main thoroughfare, it was a flourishing seat of great civilizations and religions. For our purpose, most striking is the fact that Afghanistan has had three principal names each of which has lasted for centuries.

The three principal names-Aryana in antiquity, Khurasan in the medieval era, and Afghanistan in modern times-have distinguished this land throughout its history, although at times Herat, Bactria, and Kabul have had kingdoms of their own.

Modern Afghanistan is almost co-extensive with the land mentioned in the old Greek as Ariana, in the old Persian as Airya or Airyana, in San- 


\section{xvi Introduction}

skrit as Arya-Vartta or Arya-Varsha, and in Zend as Eriene-veejo. Situated between India and Persia (Pars), Aryana was a geographical and cultural rather than political name. Boundaries on the west and north were imprecise, but those on the east and south were the Indus River and Indian Ocean. Aryana's inhabitants, the Arya, were identified with the regions in which they lived and spoke languages that "were, no doubt, for the most part very much akin, as they were in fact natives of one and the same country." 1 The name Aryana lasted for 1,500 years from the Avestan period (ca. 1000 B.C.) to the fifth century of the Christian Era.

The word Khurasan, signifying the "land of the rising sun" (i.e., the eastern land), appeared in the second century of the Christian Era but was applied to the land east of Iran in the fifth century. During the Sasanid period (A.D. 208-561) it was a part of Eran Shahr and called the fourth climate (iqlim). Later, its eastern boundary reached India. ${ }^{2}$ The Afghan historian, Mir Ghulam Muhammad Ghobar, writes that, "For fourteen centuries Khurasan was applied initially to parts of Afghanistan and later to the whole country and is still in use for a small region to the northwest of it." 3 When strong governments-such as those of the Tahirid (A.D. 821-873), Saffarid (A.D. 867-1495), Ghaznavid (A.D. 977-1186), and Ghurid (ca. A.D. 1000-1215) - arose in Khurasan their rulers were invariably called caliphs in Baghdad, amirs in Khurasan. Even down to the nineteenth century the name Khurasan, signifying Afghanistan, was in use along with the words Pashtunkhwa, and Sarhad. ${ }^{4}$ It was only toward the end of that century that the appellation Afghanistan replaced the word Khurasan completely.

Afghanistan, however, is not a new name. It is generally believed to have appeared with the accession of Ahmad Shah Durrani in 1747; but, so far as is known, this word was applied in a political sense to a land for the first time in the third decade of the fourteenth century by Saifi Herawi in his The History of Herat. ${ }^{5}$ He mentions it very frequently along with other names, such as Shiberghan, Turkestan, and Khurasan. Apparently, Afghanistan had been independent after the onslaught of Chinggis Khan (reign, A.D. 1206-1227) and was ruled by local rulers of its own until they were overcome by the Kurt rulers of Khurasan in Herat (1245-1381). All this time the word Afghanistan generally referred to a land situated between Ghazni and the Indus River with its main center at Mastung (Quettar). In other words, the lowlands and highlands of the Sulaiman Mountains where the Afghans have lived for centuries were included in Afghanistan. Writers subsequent to Saifi Herawi have described Afghanistan with more or less the same boundaries.

Three points must be further noted in connection with the name Afghanistan. First, the name signified the same land even during the height of the Durrani Empire when, in addition to present-day Afghanistan, it also included Persian Khurasan, Turkestan, the Panjab, Kashmir, Herat, and Baluchistan. Afghan historian Sultan Muhammad Durrani wrote that in the time of Ahmad Shah Durrani Afghanistan was 


\section{xvii ses}

situated, "between India, Persia and Turkestan." ${ }^{6}$ In 1809 Mountstuart Elphinstone observed that the Hindu Kush constituted Afghanistan's northern bulwark. ${ }^{7}$ It was only in the second part of the nineteenth century that this name began to be applied to the land situated between the Durand Line and the Oxus River, that is modern Afghanistan. Only after all its boundaries were agreed upon and demarcated by the British government of India in agreement with the governments of Persia, Russia, and Afghanistan (much to the disadvantage of the last) did the use of the name become usual. This period also coincided with a northward migration of the Afghans who turned the provinces beyond the Hindu Kush from mere dependencies into integrated parts of Afghanistan.

The second point to stress is the fact that Afghanistan was a name employed only by non-Afghans, notably Persians, ${ }^{8}$ until the word passed on to the Afghans themselves in the last quarter of the nineteenth century. Previously the Afghans spoke of their land either as Pashtunkwa (the homeland of the Pashtuns) or Roh (the mountain). Roh included a more extensive land that stretched as far as the Helmand River to the west. ${ }^{9}$

The third point to observe is that the people who principally established the Afghan kingdom were known by the names of Afghan, Pashtun, and Pathan.

Pathan is a comparatively recent name and was originally applied by the Indians to Afghans. Opinions differ as to how it arose. Some are of the opinion that it is derived from the word Pashtan, ${ }^{10}$ while others hold that when the Afghans settled in the Pathna District of the province of Bihar in India, the Indians called them Pathans as residents of Pathna. ${ }^{11} \mathrm{Be}$ it as it may, since the twelfth century the name has been applied to the Afghans in India. Later, it signified the Afghans of the Sulaiman Mountains as well, and English writers tried to distinguish these Pashtuns (Pathans) from the Afghans inside modern Afghanistan as if they were two different peoples. The people, however, refer to themselves not as Pathans, but as Pashtuns.

The name Pashtun (or Pakhtun) is the original and oldest of all. It appeared for the first time in the Rig-Veda, the sacred book of the Hindus, as Pakhtas some three thousand years ago. ${ }^{12}$ Later Herodotus (484-431 B.C.) used the word Pactyan for the residents of "the country of Pactyica." 13 Subsequent writers in general have identified the Pactyans and Pakhtas with the Pashtuns of the Sulaiman Mountains. The noted Indian historian R. C. Majumdar, for instance, writes that, "Pactyan is perhaps represented by the ethnic name of Pakhtun or the Indian Pathan." ${ }^{14}$ Indeed, Herodotus' word Pactyica is to this day in use as the name, Pactya, for an eastern region of Afghanistan.

The word Afghan has an interesting history. It is linked with the Asvaka ("horse people") of Gandahara in the Mahabarata, the Sanskrit epic composed about 1200 B.C. ${ }^{15}$ Asvaka and Asvaghana are the same compound Sanskrit word and both refer to the land of the horse people as well as its inhabitants. ${ }^{16}$ The Sulaiman Mountains have a 


\section{xviii Introduction}

very long history as a horse-breeding area, so the word Afghan originally signified the land as well as people. With the passage of time it also occurred frequently in other sources: in Persian as the word Abgan (also Avgan), ${ }^{17}$ in Hindi as Avagana ${ }^{18}$ and in Chinese as O-Po-Kien ${ }^{19}$ Arab geographers have invariably noted it as Afghan ${ }^{20}$ As is evident, the name Afghan, like Pathan, was given to the Pashtuns by others. The Afghans refused to call themselves by this name ${ }^{21}$ until recently when it was adopted as a national name for all citizens of Afghanistan regardless of language, religion, and ethnic identity.

The Pashtuns are closely linked with the Tajiks, the second major group of people in Afghanistan. Philological, anthropological, and historical research has shown that in ancient times the Tajiks and Pashtuns lived in the same geographical area. According to Georg Morgenstierne, Pashto, the language of the Pashtuns, originally belonged to the northeastern branch of the Aryani languages, represented today by the Pamir dialects (Shughni, Munji, and so forth), and has some features that point to a special relation to the ancient Bactrian languages of the Surkh Kotal inscription. ${ }^{22}$ The anthropologist H. F. Schurmann advances the view that the kind of economy that Elphinstone has described for the Afghans of the Sulaiman Mountains indicates an archaic type of mixed agriculture-pastoralism of a type often found among certain mountain Tajiks. More specifically he concludes that the "real Afghans" form part of that vast group of mountain peoples of Aryani stock that is best represented by the mountain Tajiks. ${ }^{23}$ The historian Ghobar advances a similar view. In Herodotus' times the Tajiks (ancient Dadicae) lived along with Pashtuns in the seventh satrapy of Darius (that is, the Sulaiman Mountains), and they "were all reckoned together." ${ }^{24}$ A people called Dadi, considered to be the descendants of these ancient Dadicae, still lived among the Kakar Pashtuns down to the last quarter of the nineteenth century. ${ }^{25}$ According to Ghobar most of these Dadicae, because of the pressure of the Pashtuns, had much earlier left for Chitral, Badakhshan, and the lands beyond the Oxus, as well as for Siestan, Baluchistan, and other places in central Afghanistan. ${ }^{26}$ It is then no wonder that the Pashtuns and Tajiks, who combined constitute most of the inhabitants of Afghanistan, have always shown a united front to all invaders and helped to preserve Afghanistan.

A bare sketch of the attempts made by the Pashtuns to set up states in various lands down to the time of Amir 'Abd al-Rahman is now in order. Among the Pashtuns forms of elementary government can be traced from ancient times when they appeared in Ghore and the Sulaiman Mountains. It was, however, in the tenth century of the Christian Era that Shaykh Hamid Ludi organized his tribesmen into a state to be able to defend the frontier district of Baluchistan against the Hindus of India. Later, in the middle of the fifteenth century, Sultan Bahlul Ludi established a well-structured state and an Afghan empire in India modeled basically on the state founded by Shaykh Hamid Ludi. Sultan Bahlul Ludi was able to create a sort of Afghan confederacy by dividing 
his vast empire among his relatives as amirs. Among his accomplishments were the revival of the Dehli sultanate, extension of its boundaries (Panjab to Bihar), and the rehabilitation of its prestige after years of decline. ${ }^{27}$ His dynasty was supreme in India for three-quarters of a century (1451-1526). Shortly after the 1526 overthrow of the Ludi dynasty by Babur, the founder of the Mughal Empire, Sher Shah Afghan founded the short-lived Sur dynasty (1530-1555). As a person, Sher Shah outshone all Afghan rulers who lived before him or came after him. Sher Shah whose reign "proved to be one of the best India had ever enjoyed" built "an excellent administrative system which was to become the foundation upon which the later Mogul administration was based." 28

During the long period of the Mughal rule in India and Afghanistan, Bayazid Ansari (1525-1581) initiated an independence movement, the Roshania, among the separate tribal communities of the Sulaiman Mountains. He brought into existence a rudimentary form of supratribal organization at the same time that he waged a fierce struggle against the Mughals. For various reasons, however, the organization did not develop, and by 1630 the movement was crushed. Later, the great warrior and poet Khushhal Khattak (1613-1689) and others revived the struggle for independence along nationalistic lines, but in the end they too were unable to succeed.

The Pashtuns who in modern times overthrew foreign yokes and organized states were the Ghilzays and Durranis. Mir Wais Ghilzay was the forerunner of Afghan independence. In 1707 he made Kandahar independent of Safavid Persia that had ruled it since 1622. In 1722 his son even occupied Isfahan. At the same time the Durranis also terminated the Persian occupation of Herat and organized an independent state of their own. Soon, however, Nadir Shah Afshar ended the rule of both in Isfahan and Herat, as well as in Kandahar. Nadir Shah's occupation of Afghanistan also did not last long, and after his assassination in 1747 his empire collapsed. The Durranis who had returned to Kandahar chose Ahmad Shah as their king. Under Ahmad Shah they not only made the whole of Afghanistan independent, but also established an empire. This time the state the Durranis established proved permanent, although the empire collapsed by 1818 . Ahmad Shah's dynastic rule also came to an end, mainly as a result of the wars of succession among his numerous grandsons. Since the tradition of dynastic rule among the Durranis had been well established and since there was a strong desire on the part of all Muslims to have a ruler of their own able to defend Islam in a land which for centuries had proved capable of supporting a state, the Muhammadzay dynasty gradually replaced the old dynasty. In 1836 Dost Muhammad Khan was proclaimed as amir al-mu'minin (commander of the faithful). He was well on the road toward reunifying the whole of Afghanistan when the British, in collaboration with an ex-king, invaded Afghanistan in what is known as the First Anglo-Afghan war (1839-1842). After some resistance Amir Dost Muhammad Khan was deported to India. The British rule 


\section{$\mathrm{xx}$ Introduction}

did not last long. After the annihilation of all of the British troops Afghanistan once again became independent, and the exiled amir was allowed to reoccupy the royal throne in 1843 . During his second reign Amir Dost Muhammad reunified the whole of Afghanistan by noteworthy statesmanship rather than by force, usually a distinguishing feature of Afghan politics. Perhaps the most distinguishing feature in this period is the beginning of the consolidation of the central government in a reunified Afghanistan. His son and successor Amir Sher 'Ali Khan, after he overcame his rival brothers in a series of bloody civil wars in the 1860s, was even more successful in consolidating the state. The high points of the state he instituted were a large modern army, the establishment of the state-controlled civil and military schools, of a consultative assembly, the expansion of the existing bureaucracy, and the rationalization of the system of taxation. In spite of this, tribal communities, as well as individuals, were able to preserve their traditional autonomy. The state in this period was well on the way toward modernity. The second British intervention in 1878 disrupted this process, and the country was again plunged into a war with the British until the accession of Amir 'Abd al-Rahman Khan (pronounced 'Abdur Rahman Khan) in 1880.

The British, shortly after the accession of the new amir, withdrew from Afghanistan, although they retained the right to handle Afghanistan's foreign relations. Partly because of the desire of both Russia and Britain (whose empires by now had sandwiched Afghanistan) not to let their empires meet in this part of the world and partly because Afghan resistance to foreign invasion in the past had been so formidable, these two powers ultimately decided to leave Afghanistan as a buffer state and to her own destiny. This decision by the two powers and the fact that Britain supported Amir 'Abd al-Rahman Khan with weapons and money during his numerous internal crises gave the amir the excuse, leverage, and opportunity to institute a highly centralized form of absolutist government to an extent that neither his predecessors nor his successors were able to emulate. In his reign modern Afghanistan began to emerge.

The emergence of modern Afghanistan has two main characteristics. First, as noted, Afghanistan's boundaries with her neighboring countries were almost all demarcated for the first time. In this demarcation Afghanistan lost vast territories. Of particular significance was the loss that resulted from the Durand Agreement concluded in 1893 in Kabul between Mortimer Durand, foreign secretary to the British government of India, and Amir 'Abd al-Rahman. By this agreement the core of the original Afghanistan came to be regarded as within the British sphere of influence. This loss of territory led to the rise of a strong irredentist movement inside Afghanistan that has ever since strained her relations with her eastern neighbors.

Second, also for the first time, the central government extended direct control over the affairs of tribal groups and regions in a sharp departure from the former system of administration that had allowed 
various degrees of autonomy for tribal communities according to their locations and significance. In the context of Afghanistan this task was very difficult, in some ways comparable to the creation of Afghanistan in the middle of the eighteenth century. This process was the subject of my Afghanistan, A Study in Internal Political Developments, 1880-1896. Here only a brief sketch of the main internal political developments is given.

More than forty internal disturbances took place during the reign of Amir 'Abd al-Rahman. They fall into three main categories: those that were the result of dynastic rivalry, those that followed the imposition of taxes and rigid administration, and those that were caused by the extension of government authority into hitherto independent regions. Of all the disturbances, those of the first group were the most serious. In this group, the amir's adversaries were his cousins, Sardar $\mathrm{Mu}$ hammad Ayyub and Sardar Muhammad Ishaq who, like the amir, had legitimate claims to the throne since their fathers had been amirs of Afghanistan. In addition, each sardar commanded a large body of the regular army. In the case of the disturbance of Sardar Ayyub, the amir still had not firmly established his rule in June 1881 when his rival occupied Kandahar from his base in Herat. Ayyub had the support of the Durranis, who regarded the amir as an Anglophile since he had acceded to the throne in Kabul in 1880 partly with British support after eleven years of exile in Russian Turkestan. That Muhammad Ayyub was a son of Amir Sher 'Ali, who had lost his throne for his opposition to British designs on Afghanistan, and that he had defeated a British force in 1880 at Maiwand had made him a popular hero. In battle at Kandahar on 22 September 1881 Ayyub's larger army was decisively defeated, because of the amir's military skill (unlike Ayyub, the amir commanded his army in person); British support in money and weapons; and, most important, the desertion of a portion of Ayyub's army in a critical moment. It was actually only after the banishment of Ayyub in the same year to Persia that the amir was able to extend his rule over that area of Afghanistan that had formerly been ruled by his predecessor Amir Muhammad Ya' qub, the elder brother of Ayyub, whom the British had deported to India in December 1879.

Seven years later in 1888 , the second formidable revolt was staged by Sardar Muhammad Ishaq, who had been the almost autonomous governor of Turkestan since 1880. Like Sardar Ayyub, Sardar Ishaq was also popular, particularly with the people of Turkestan, but also with those of other regions, mainly for his humane system of administration that was in contrast to the autocratic rule of the amir. The popular discontent generated by the amir's rule was so strong that all troops of the amir in Badakhshan joined the rebel sardar and that a portion of the amir's army deserted to him in the battlefield. The situation for the amir was made worse by illness that made him unable to lead his army in person. Luckily for the amir, the sardar proved such an incompetent soldier that on the day of the battle in Gaznigak (27 September 1888) he left his almost victorious army behind and escaped to Bukhara. He 
did so because he thought that the portion of the amir's army that was deserting to his side was trying to capture him. Had Ishaq provided sound leadership to his enterprising Ghilzay-dominated army, backed by the general populace of Uzbeks and Turkmen, he might have changed significantly the course of Afghanistan's political history. His escape brought about, among many other things, a strong northward migration, mainly by the Pashtuns, who ultimately outnumbered every other single ethnic group of the area and changed Turkestan from a dependent to an integral part of Afghanistan.

The revolts that resulted from the imposition of heavy taxes were numerous. Almost all tribal groups rebelled against the government at one time or another. The Shinwaray Rising (1882-1892) is the most representative of all; but because of its wider implications the Ghilzay Rebellion will be briefly discussed here.

Concerning the Ghilzays of this period two things should be borne in mind. First, except for those who lived near Kabul and along the main roads, most Ghilzays were virtually autonomous; their elders and mullas managed their affairs for them. Second, the revenue they paid to the government through their elders was very light. In addition, the Hotakay section of the Ghilzays and certain persons, like Mulla Mushk-i-'Alam, who held extensive tracts of lands were exempt from paying revenue to the government. What disturbed the tribespeople themselves was the takeover of their internal administration by the central government and the imposition of land revenue in 1886 at the rate of one-third, one-fifth, and one-tenth of the produce, depending on the quality of land. Also, in the same year the government imposed on the Ghilzays, including their mullas, varieties of other taxes, although the amir in 1881 had freed them from paying poll tax (tawan-i-sar), which, until then, the Ghilzays had paid to the government. Other measures that stirred the tribe to action included the assessment of revenue on the hitherto revenue-free lands owned by some elders and the resumption by the state of those lands that certain elders enjoyed in lieu of their allowances. Furthermore, the imprisonment of insubordinate elders, especially those who had distinguished themselves by fighting the British during the occupation period, such as Ghazi Muhammad Jan Wardak, 'Ismat Allah Jabar Khel, and others, disturbed the tribe to the extent that in October 1886 their elders, under the leadership of Mulla 'Abd al-Karim Andar and Muhammad Shah Hotakay, instituted a great rising. Initially they scored victories against contingents of the armies that were stationed in Muqur and Ghazni, but they were dispersed by the army sent from Kabul in the winter of 1886 . During the late spring of 1887 all sections of the tribe, including a portion of the Ghilzay in the amir's army, reassembled in large numbers in the Muqur area; but, since the tribe had little money and few weapons and since the rising did not spread significantly beyond their own territory (although other tribes refused to assist the amir against the insurgents and even a few non-Ghilzay tribes rose in their support), the large, well-armed regular army finally crushed the rising in a series of 
engagements that continued until the autumn of 1887 . This last major rising of the Ghilzays led, among other things, to the permanent improvement of the hitherto estranged relations between the amir and parts of his own Durrani tribe and to the reimposition of revenue and other taxes on the Ghilzays, against which they had rebelled.

The pacification of the Hazaras and the conquest of Kafiristan represent the extension of government controls over areas that were, up to 1880 , partially and wholly independent. The Shi' ite Hazaras who occupied the central highlands, the Hazarajat, during the period from 1229 to 1447, enjoyed a relatively high degree of autonomy until the amir's accession. This autonomy was mainly the result of their mountainous territory, although certain areas of their extensive region provided green pasture and fertile land for its inhabitants, who were said to number 340,000 in the second half of the nineteenth century. Afghan rulers in the past had gradually extended government authority over thirteen of the fifteen different tribal communities of the Hazaras. During the first decade of the amir's reign only Uruzgan had remained completely independent, whereas the rest had been brought still more closely under government control, although their religious and secular elders (sayyeds and mirs) had still retained most of their traditional power over the common Hazaras (most of the Hazara land was owned by the mirs). In 1891 even the 44,500 Hazaras of Uruzgan submitted to the amir on certain conditions. In that year, however, 10,000 troops entered Uruzgan under the leadership of a civilian governor, Sardar 'Abd al-Quddus. Soon the Hazaras of Uruzgan rose in a revolt that ultimately involved most Hazaras of the Hazarajat. The trouble started when the amir, following the entry of the army, initiated a policy of separating the Hazara elders from their tribespeople on the assumption that in the class-differentiated society of the Hazaras, where the elders had exploited the common Hazaras, the latter would not support the former. This policy, after initial success, failed utterly, mainly because of the mishandling of the situation by corrupt officials. These officials, especially the military, raped the Hazara women, took possession of their qal' as (forts), and oppressed the Hazaras without distinction; they also began disarming the Hazaras and surveying their lands for revenue purposes. The Palo section of the Sultan Muhammad tribe initiated the rising, which resulted in the destruction of the greater part of the national army. Since the Hazaras were Shi' as and were on bad terms with their Sunna neighbors the amir turned the rising into a sectarian war. He successfully enlisted the support of the Sunni tribes and of his regular army in crushing the Hazaras over a period from late 1891 to 1893 by the deployment of 100,000 troops and tribal levies. After their defeat, a large number of the Hazaras were enslaved, their land in Uruzgan was granted to the Durranis and Ghilzays, and Pashtun nomads were allowed to take Hazara pastures for their own flocks. A large number of the Hazaras migrated. The Hazara power was, as a consequence, broken to the extent that it never again challenged the government. 
The last campaign waged during the amir's reign was for the conquest of Kafiristan, which had remained independent for centuries. Its inhabitants, who were known to the Muslims as Kafirs, were known among themselves by their various tribal names and spoke mutually unintelligible languages. The difficult terrain of their country had enabled them to repulse previous attempts to conquer their land by many Muslim rulers in the past. By 1880 , however, the Kafirs were no match for the amir's government, owing to their small number $(60,000)$, their primitive weapons (spears, bows, arrows, and some rifles), and the inroads of Islam into parts of their land, especially the border areas. Except for his persuasion of the Kafirs to accept Islam, the amir, until the conquest of their land in 1895-1896, largely left them unmolested, mainly because of his preoccupation with other rebellions and, to a certain extent, because of the proximity of eastern Kafiristan /the Bashgal Valley) to Chitral, which had been placed under indirect British control through the Raja of Kashmir. By 1895 when the boundary with Chitral had been demarcated and other rebellions suppressed, the amir feared that the occupation of the Pamirs by Russia and of Chitral by Britain might endanger the integrity of Afghanistan through the still independent Kafiristan. In the winter of 1895 he ordered the conquest of Kafiristan by the army and tribal levies. This conquest was accomplished relatively easily. Compared with rebellious Muslim tribes the defeated Kafirs were treated mildly, but their whole-scale conversion to Islam was stressed. This conquest increased the amir's prestige at home and abroad. After that no significant uprising took place during the amir's reign, and he concentrated on the consolidation of the state. 